THE DUTY TO EFFECT AN APPROPRIATE MODE OF PAYMENT TO MINOR PENSION BENEFICIARIES UNDER SCRUTINY IN DEATH CLAIMS

ISSN 1727-3781

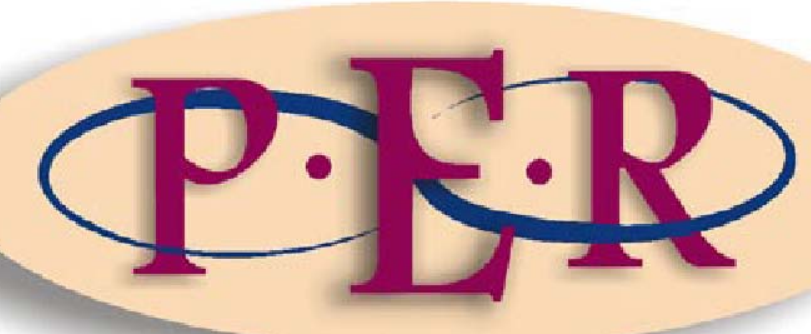

2009 VOLUME 12 No 2 


\title{
THE DUTY TO EFFECT AN APPROPRIATE MODE OF PAYMENT TO MINOR PENSION BENEFICIARIES UNDER SCRUTINY IN DEATH CLAIMS
}

\author{
M Mango* and N Dyani**
}

\section{Introduction}

The duty to effect an appropriate mode of payment to minor beneficiaries under section 37C of the Pension Funds Act 24 of 1956 (the Act) has been the subject of several determinations issued by the Pension Funds Adjudicator (the Adjudicator). Section 37C, as amended, of the Act contemplates six modes of payments of death benefits to minor beneficiaries and gives the board of management of pension funds (herein the board) discretion to decide an appropriate mode of payment. ${ }^{1}$ Section $37 \mathrm{C}$ as amended provides in pertinent part that:

(1) (a) If the fund within twelve months of the death of the member becomes aware of or traces a dependant or dependants of the member, the benefit shall be paid to such dependant or, as may be deemed equitable by the board, to one of such dependants or in proportions to some of or all such dependants.

(2) For the purpose of this section, a payment by a registered fund to a member nominated trustee contemplated in the Trust Property Control Act, 1988 (Act No. 57 of 1988); a person recognised in law or appointed by a Court as the person responsible for managing the affairs or meeting the daily care needs of a dependant or nominee; or a beneficiary fund, for the benefit of a dependant or nominee contemplated in this section shall be deemed to be a payment to such dependant or nominee.

(3) Any benefit dealt with in terms of this section, payable to a minor dependant or minor nominee, may be paid in more than one payment in such amounts as the

* BA (Morehead State, USA) JD (Michigan State, USA) LLM (Wayne State, USA) PG Dip (UCT); Senior Lecturer, School of Law, University of the Witwatersrand.

** LLB, LLM (Western Cape); Lecturer, School of Law, University of the Witwatersrand. We would like to thank Sabelo Gumedze and the referees for their insightful comments on the earlier version of this paper

1 In terms of s 17 of the Children's Act 38 of 2005, the age of majority has been changed from 21 to 18 as of 1 July 2007 . This means that upon reaching the age of 18 , a child will no longer be regarded as a minor and for purposes of $\mathrm{s} 37 \mathrm{C}$ and may be entitled to receive their benefits at age 18 . This will require pension funds to change their rules or practice in relation to how payments of death benefits under the Act are made. 
board may from time to time consider appropriate and in the best interests of such dependant or nominee. ${ }^{2}$

The six alternative modes of payment contemplated in the above provision of the Act are the following: The first is direct payment to a minor beneficiary; ${ }^{3}$ the second is direct payment to the minor's guardian; ${ }^{4}$ the third is payment into a deceased member nominated trust; ${ }^{5}$ the fourth is payment in installments; ${ }^{6}$ the fifth is payment to a person recognised in law or appointed by a court as the person who is legally responsible for managing the affairs of a beneficiary or meeting his or her daily care needs ${ }^{7}$; and the sixth, is payment to a beneficiary fund. ${ }^{8}$

This note will focus on the third mode of payment, which is payment into a trust arrangement in favour of a minor beneficiary as contemplated in terms of section 37C (2) of the Act. The problem with this mode of payment is that sometimes it entails a decision by the board on whether or not a parent or guardian should be deprived of the right to administer benefits on behalf of minor beneficiaries. It is important to point out that the Financial Services Laws General Amendment Act 22 of 2008, which was promulgated on 30 September 2008 to amend section 37C of the Act, has introduced a new concept of a pension fund organisation known as a beneficiary fund. Accordingly, the beneficiary fund is a pension fund organisation which is regulated under the Act. The purpose of a beneficiary fund is to accept payments of benefits that were previously paid to trusts by pension funds, when boards either deprived a parent or guardian of their ability to administer the benefits or decided it was in the best interest of the minor beneficiary to pay the money into a trust

2 S 37C of the Act as amended by s 15 of the Financial Services Laws General Amendment Act 22 of 2008.

3 S 37C(1) of the Act. See also Mafe $v$ Barloworld (SA) Retirement Fund Respondent PFA/FS/13033/07/CN at par 34 (reasoning that while direct payment to a minor is not explicitly spelt out in the Act, it can be inferred from s 37C(1) and can be appropriate in certain circumstances). See also, Marx and Hanekom Manual 217 (arguing that the board in terms of $\mathrm{s} 37 \mathrm{C}$ must effect an appropriate mode of payment, and noting that the first enquiry in this regard is whether payment should be made directly to the minor himself).

4 See $s 37 \mathrm{C}(1)$ of the Act.

5 S 37C(2)(i) of the Act.

6 S 37C(4) of the Act.

7 S 37C(2)(ii) of the Act.

8 S 37C(2)(iii) of the Act. 
arrangement. While this note will primarily speak of payment into trust arrangements, the above amendments stipulate an additional mode of payment whose practical considerations mirror the trust arrangement. ${ }^{9}$ The aim of this note is to examine the criteria under which the board may deprive a guardian of the right to administer benefits on behalf of minor beneficiaries. This examination is conducted within the context of the approach adopted by the Adjudicator in four specific determinations decided prior, but relevant, to the above amendments to the Act, where the board in each case unlawfully deprived a guardian of the right to administer death benefits in favour of a minor beneficiary. ${ }^{10}$ Therefore, the note will discuss four specific determinations and thereafter comment about the criteria to be used by practitioners. The note argues that these determinations should be welcomed because of their progressive interpretation of the Act and for setting an important precedent for pension fund practitioners and boards. In each case, the Adjudicator found a violation of section $37 \mathrm{C}$.

The note also criticises the remedy granted in two of the determinations, namely Moralo v Holcim South African Provident Fund, and Mafe v Barloworld (SA) Retirement Fund Respondent, and argues that the Adjudicator's ruling on these matters was arbitrary and capricious because it disregarded its own precedent in Lebepe $v$ Premier Foods Provident Fund. We therefore submit that the Adjudicator should have ordered the boards in Moralo $v$ Holcim South African Provident Fund, and Mafe $v$ Barloworld (SA) Retirement Fund Respondent to pay all the benefits directly to the complainants and guardians in those determinations.

9 Swanepoel 2009 www.sanlam.co.za/ 1.

10 The four determinations are Kowa $v$ Corporate Selection Retirement Fund PFA/GA/14151/ 2007/SM unreported; Lebepe v Premier Foods Provident Funds PFA/NP/5947/2005/RM; Moralo v Holcim South African Provident Fund PFA/GA/5400/2005/ZC; Mafe v Barloworld (SA) Retirement Fund Respondent PFA/FS/13033/07/CN. 


\section{The determinations}

\subsection{Kowa v Corporate Selection Retirement Fund ${ }^{11}$}

The complainant in this matter was the mother of the deceased, who passed away in 2005. The deceased was employed by Paul's Muesli CC ("the employer") and was a member of the Corporate Selection Retirement Fund (the CSRF) until he passed away. Upon his death, a total lump sum death benefit of R62 158.47 became available for distribution to his beneficiaries. After completing its investigation regarding the circle of beneficiaries, the board decided to pay the complainant an amount of R3000.00 on the basis that she had been nominated as the beneficiary by the deceased. The balance was placed in a trust for the benefit of the deceased's minor child, Kabelo Justice Kowa.

The complainant lodged a complaint with the Office of the Pension Funds Adjudicator (OPFA) in terms of section 30A of the Act and argued that the board of the CSRF erred when it paid the minor child's share of the benefit into a trust. The complainant's contention was that the deceased had nominated her as the sole beneficiary of his death benefit, and therefore, she should have been awarded the whole amount of the death benefit in the form of a lump sum because she was taking care of the deceased's minor child.

In resolving this complaint, the Adjudicator first held that the complainant could not claim that she was entitled to receive the whole amount of the death benefit merely on the grounds that the deceased had nominated her to receive $100 \%$ of his benefit. In any event, the Adjudicator noted that the complainant had been nominated to receive the whole amount of the death benefit before the birth of the deceased's minor child, who qualified as a dependant in terms of section $37 \mathrm{C}$ of the Act. 
With regard to the payment of the minor child's share of the death benefit into a trust, the Adjudicator noted that section 37C(2) of the Act regulates the mode of payment of a death benefit into a trust in favour of a minor dependant or minor nominee. In interpreting the section $37 \mathrm{C}(2)$, the Adjudicator reasoned that when paying a death benefit to a minor, the benefit is normally paid to the guardian of the minor. As a legal guardian of a minor child a parent has a duty, inter alia, to administer the property and assets of her/his minor child. Therefore, based on this reasoning the Adjudicator held that the payment of the minor child's benefit to her/his legal guardian should be done in the ordinary cause of events unless there are cogent reasons for depriving the guardian of the duty to take charge of her/his minor child's financial affairs, and the right to decide how the benefit due to the minor should be utilised in the best interests of the minor child. ${ }^{12}$

The Adjudicator noted that common law grants a legal guardian, as against a custodian or a care giver, greater responsibility and authority to make decisions regarding the welfare of a minor child under his/her guardianship, subject to those decisions being in the best interests of the minor. ${ }^{13}$ On the facts of this case, it was clear to the Adjudicator that the minor child had not been survived by any legal guardian as both of his parents had passed away, and that the deceased's minor child was being cared for by the complainant who was his grandmother. According to the Adjudicator, it was clear that the complainant was acting as the minor child's guardian because she took care of his daily needs.

In addressing the CSRF submission that the complainant was a caregiver and not a legal guardian, and thus its refusal to pay her the death benefit, the Adjudicator explained that:

guardianship is used in two senses. In the first sense, the broader definition of guardianship is equated with parental authority and includes all other responsibilities. This is typically used to describe the legal status of the parents of a marital child in their capacity as natural guardians. In the second sense, the

12 Par 18, citing Malatjie $v$ Idwala Provident Fund [2005] 1 BPLR 45 (PFA) par 12 and Dhlamini v Smith [2003] 7 BPLR 4894 (PFA) 4901C-F.

13 Par 19, citing, Robinson v Boerhringer-Ingelheim Pension Scheme [2003] 10 BPLR 5234 (PFA) 5237I-J. 
narrower definition, guardianship means that portion of parental authority which relates to the control and administration of the child's estate. [...] Further, section 18(1) of the Children's Act No 38 of 2005 sets out the parental responsibilities and rights to include '(a) to care for the child; (b) to maintain contact with the child; (c) to act as guardian of the child; and (d) to contribute to the maintenance of the child.' Thus, any person who administers and safeguards a minor's property and property interests should be regarded as a guardian. ${ }^{14}$

On the facts of this case, it was clear to the Adjudicator that the complainant was the one who attended to all the daily needs of the deceased's minor child. It was also clear that the relationship between the complainant and the minor child was not temporary as in the case of a temporary care-giver. Therefore, the Adjudicator held that the complainant was in the same position as that of a natural guardian.

Regarding the question of whether a guardian should be deprived the right to administer the benefit, the Adjudicator noted that there is an onerous duty on the board to carefully consider the facts of each case before depriving anyone, who acts as a guardian of minor child, of the right to administer the financial affairs of the minor child. According to the Adjudicator, the board must consider the following relevant factors in making this decision: (1) the amount of the benefit; (2) the ability of the guardian to administer the moneys; (3) the qualification (or lack thereof) of the guardian to administer the moneys; (4) and the benefit should be utilised in such a manner that it can provide for the minor until he or she attains the age of majority. ${ }^{15}$ The Adjudicator found that the board fettered its discretion when it routinely paid the minor child's share into a trust without an investigation into the ability of the complainant to administer the affairs of the deceased's minor child and consideration of the above factors. On the facts of the case, the Adjudicator reasoned that the board had made no attempt to investigate the complainant's ability to administer the financial affairs of her grandchild, her qualification and the nature of her relationship with the minor child. Instead, the only reason advanced by the board for its decision to pay the minor's share into a trust was that the complainant was not a legal

14 Par 22. Original emphasis.

15 Par 23, citing, Ramanyelo v Mine Workers Provident Fund [2005] 1 BPLR 67 (PFA) par 16. 
guardian but merely a caregiver of the minor child. Further, the Adjudicator explained that in appropriate circumstances the amount involved and the cost implications of paying the minor child' share into a trust, vis-à-vis those other suitable options, are highly relevant considerations that the board should take into account ${ }^{16}$ Moreover, the best interests of the minor child are paramount, and should prevail over all other considerations. ${ }^{17}$ Accordingly, what is actually in the best interests of a child is a question of fact in each case; that it might be in the best interests of a minor child for the board to pay his/her share into a trust, but this decision should be taken after all relevant factors have been carefully considered. In the end, the Adjudicator ruled that the board fettered its discretion when it routinely paid the minor child's share of the benefit into a trust without an investigation into the ability of the complainant to administer the affairs of the deceased's minor child and consideration of the factors announced in Ramanyelo v Mine Workers Provident Fund.

\subsection{Lebepe v Premier Foods Provident Fund ${ }^{18}$}

In this case, the complainant was the wife of Mr Lebepe (the deceased), who was a member of the Premiere Foods Provident Fund (Provident Fund). Following the deceased's death, a death benefit in the amount of R233 000.00 became available for distribution. The board of the Provident Fund identified the complainant and her three minor children as dependants of the deceased, and distributed R33 000.00 to the complainant and placed the remaining amount into a trust. The complainant as guardian of the three minor children received a total of R675.00 per month from the trust in respect of maintenance of the children.

The complainant was unhappy about the decision of the Provident Fund and claimed that she had been arbitrarily deprived of her right to administer the benefit on behalf of her minor children. She also claimed that the Provident Fund was unjustified in setting up the trust considering that she could

16 Par 24, citing, Dhlamini v Smith [2003] 7 BPLR 4894 (PFA) par 23.

17 Par 25, citing, Fletcher v Fletcher 19481 SA 130 (A) 135.

18 PFA/NP/5947/2005/RM. 
administer the benefit herself. She indicated that she had passed grade 11 and had attended several financial management courses at educational and business institutions. To demonstrate her ability to administer the benefit, the complainant submitted that she had approached an insurance company for a quotation of an interest payment she would receive on an endowment policy to the value of R200 000.00. The insurance company had quoted a monthly interest of R1200.00 with fees that were far less than the monthly administration costs deducted in respect of the children's trust.

Regarding the decision to place the benefit into a trust or endowment policy, the Adjudicator held that it was not the role of the Adjudicator to enter into the realm of speculation regarding advantages or disadvantages of trusts as compared to endowment policies. However, the Adjudicator cautioned that the board must proceed with utmost care and diligence when considering all investment vehicles, including when assessing the perceived security offered by trusts.

On an inspection of the rules of the Provident Fund, it emerged that the rules provided that payment of any death benefit had to be made in terms of section 37C. According to the Adjudicator, it is clear from section 37C that when paying a benefit to a minor child, the board has three options. Furthermore, the Adjudicator reasoned that it is apparent from section $37 \mathrm{C}$ that before the board considers an alternative mode of payment (i.e. instalments or payment into a trust), there must be good reasons in law and fact as to why the option of direct payment (that is, direct payment to the minor child or guardian) should not be followed. In other words, according to the Adjudicator direct payment is the default mode of payment under section 37C, and courts in South Africa have ruled that only in instances where it is found that a guardian was not competent or qualified to administer a minor's benefits would the interests of justice be served by paying the benefit into a trust. ${ }^{19}$ 
The Adjudicator emphasised that in determining whether a guardian should administer monies on behalf of his minor, the board must consider the relevant factors announced in Ramanyelo and adopted in Kowa $v$ Corporate Selection Retirement Fund. On the facts of this case, the Adjudicator concluded that it was clear that the board only considered the advantages of trusts contrasted with the allegedly more risky investment in endowment policies. Furthermore, the fact that the complainant stated that she was competent in managing money and that she had received formal training in financial administration, including her independent investigation of other investment vehicles, demonstrated that she was aware of the various investment options available to her. Moreover, the board of the Provident Fund admitted the complainant's competency to manage the children's benefit when they stated that "the board do not doubt the capability of the complainant to handle the monies on behalf of the minor children." Based on these findings, the Adjudicator concluded that the board failed to take account of relevant factors and fettered its discretion when making its decision on the mode of payment on the benefit. Therefore, the decision to pay the three minors children's share of the benefit into a trust was set side, and the Provident Fund was ordered to pay the complainant the remaining amount of the share of the children's benefit in full.

\subsection{Moralo v Holcim South African Provident Fund ${ }^{20}$}

The complainant was the wife of the deceased, who passed away in 2003. The deceased was a member of the Holcim Provident Fund (the fund). Upon his death, a benefit of R242 822.22 became available for distribution. The board of the fund decided to pay an amount of R28 000.00 to the complaint to cover the funeral expenses and the construction of a house that the deceased was in the process of building. The remainder of the benefit was paid into a trust by the board. The complainant lodged a complaint contending that the fund had decided to pay the remaining amount of the benefit including her share into a trust without consulting her. Her plea was for the Adjudicator to reverse the fund's decision. 
On the facts of the case, the Adjudicator held that no exceptional circumstances existed to warrant the fund's deviation from the norm of paying a benefit directly to a major or guardian. The Adjudicator was critical of the fund's assertion that it paid the complainant's share of the benefit into a trust due to the fact that she was unemployed, had 25 more years to reach retirement, and had a minor child of 5 years, as unacceptable in law. Instead, the Adjudicator reasoned that there was no evidence that the complaint was labouring under a legal disability such as prodigality, insolvency, mental disability or that she was incapable of managing her own affairs or controlling the lump sum payment. Further, the Adjudicator concluded that the fund's reasons for paying the benefit into a trust were negated by virtue of their lump sum payment to the complainant in the amount of R28 000.00 for funeral expenses, completion of the building of a house and other undisclosed reasons. The Adjudicator was critical of the fact that in the above instances of prior payments, the fund had no reservations about paying part of the benefit to the complainant in the form of a lump sum, and yet some reservations had emerged when it came to the payment of the remaining benefit.

Therefore, the Adjudicator set aside the fund's decision to pay the benefit into a trust and held that the appropriate order would be to direct the fund to pay the complainant the remaining amount of her share of the benefit in full.

\subsection{Mafe v Barloworld (SA) Retirement Fund Respondent ${ }^{21}$}

The complainant in this case was the widow of the deceased. Prior to his death, the deceased was a member of the Barloworld Retirement Fund (retirement fund). Upon his death, a benefit of R136 000.00 became available for distribution. The board of the retirement fund identified the complainant and three minor children as the dependants of the deceased. The board resolved to pay the entire amount into a trust, where an amount of R200.00 was paid out every month to the complainant. The complainant objected to the decision of 
the board to pay the proceeds into a trust. Her complaint was that the board never consulted her prior to taking this decision.

Regarding the merits of the claim, the Adjudicator concluded that the only grounds advanced by the board of the retirement fund for paying the benefit into a trust appeared to be that they were informed by the deceased's former employer that the complainant was uneducated, unemployed and incapable of handling large sums of money. However, the Adjudicator noted that there was no indication that the complainant was a person labouring under a legal disability such as insanity, prodigality or insolvency. Furthermore, from the evidence it appeared that the retirement fund had not conducted its own investigation before acting in this patronising fashion of depriving a major, with full legal capacity to manage her own affairs, of her legal right to do so. ${ }^{22}$

On the facts of this case, the Adjudicator held that by not considering the complainant's ability to manage her own separate portion of the benefits, as against managing the entire amount, the board committed a serious error in law. The Adjudicator reasoned that this error manifested itself clearly from the retirement fund's statement that it relied on the deceased's former employer's statement that the complainant was not capable of handing large sums of money as a basis for paying the benefit into a trust.

The Adjudicator also found that the board had not investigated whether or not the deceased's eldest son, who was 20 years old at the date of distribution, had achieved a measure of financial independence, which would have made the direct payment to him of his portion of the benefit appropriate. The Adjudicator reasoned that payment of a minor's benefit into a trust is provided for by the Act, but it does not mean that the board may pay the benefit into a trust without considering the default mode of payment and other alternative modes of payment. The Adjudicator further explained that the board must consider the cost implication in paying a benefit into a trust as opposed to other modes of payment. From the evidence, the Adjudicator held that this did not appear to 
have been considered at all in this case, with the board having blindly relied on the deceased's former employer's words instead of conducting its own investigation and properly applying its minds to the matter.

The Adjudicator was critical of the retirement fund's approach to this matter and held that it fettered its discretion when it failed to apply its mind with regard to the appropriate mode of payment of the complainant's share of the benefit. Furthermore, it held that the board failed to properly exercise the discretion vested in them by section 37C(1) with regard to payment of the eldest son's share of the benefit. Therefore, the Adjudicator set side the board's decision and directed the retirement fund to re-exercise its discretion properly regarding the appropriate mode of payment.

\section{Importance and implication of the determinations}

The determinations discussed above (herein collectively referred to as "the above determinations") should be welcomed because of their positive implication towards the administration of pension funds and clarity regarding a grey area in the growing and developing South African pension jurisprudence. They address an issue that has not received much-needed judicial attention over the years and clarify much that was in dispute about the circumstances under which a guardian can be deprived of the right to administer death benefits on behalf of his minor child. The above determinations are important for a number of reasons including the following:

- First, in the context of death benefit claims, all of the above determinations clearly reveal that there is an important criterion to determine the appropriate mode of payment to a guardian or minor beneficiaries. Under this criterion pension funds are required to conduct an individualised investigation into whether or not a guardian is capable of administering death benefits on behalf of the minor child or children, which includes the application of the factors announced in Ramanyelo $v$ Mine Workers Provident Fund. This criterion helps the board determine the appropriate 
circumstances in which a pension fund may deprive a guardian of the right to administer benefits on behalf of minor children in his care. Under the criteria established in the above determinations, it is critical that the board consider relevant factors ${ }^{23}$ when considering whether or not to deprive a guardian of their common law rights. It has been suggested by the Adjudicator in the above determinations that a person who is labouring under a legal disability such as prodigality, insolvency, mental disability, or incapacity to manage his own affairs, may properly be deprived of the right to administer death benefits on behalf of a minor beneficiary. ${ }^{24}$

- Second, the above determinations are important because they clarify that the board may not deprive a guardian of the right to administer benefits on behalf of his minor child merely because such a guardian is not formally educated, lives in a rural area, or has never handled large sums of money. Instead, the determinations above stand for the proposition that section $37 \mathrm{C}$ requires that the board can no longer routinely pay death benefits into a trust or a beneficiary fund under current legislation without applying their minds to the factors announced in Ramanyelo $v$ Mine Workers Provident Fund and confirmed in the above determinations, and must conduct an individualised investigation into whether or not a guardian before them is capable of administering the benefits on behalf of a minor child or children. Unlike in the above determinations, where the board decided not to pay the benefit to the guardian involved for one reason or another, in Ramanyelo $v$ Mine Workers Provident Fund, it emerged following the Adjudicator's investigation of the complaint that the fund in that case had adopted a policy in terms of which, whenever there was a benefit of R20 000.00 or more payable to a minor child, it was routinely paid into a trust arrangement regardless of the guardian's ability to administer the benefit. The above determinations clearly reject this practice, and one of the effects of the

23 See Ramanyelo $v$ Mine Workers Provident Fund par 16; Mafe $v$ Barloworld (SA) Retirement Fund Respondent par 37; and Kowa v Corporate Selection Retirement Fund par 23.

24 See, eg, Moralo v Holcim South African Provident Fund par 23; and Mafe v Barloworld (SA) Retirement Fund Respondent par 31. 
rulings in the above determinations is that all pension funds with similar practices or policies will have to change the way they handle these matters and align their practices and policies with the reasoning and rulings in the above determinations.

The other effect of the rulings is that they clarify the scope of the investigation that has to be carried out by the board. The Adjudicator has consistently interpreted section $37 \mathrm{C}$ as imposing three duties on the board. The first duty is to conduct a thorough investigation to identify the circle of potential beneficiaries i.e., dependants and nominees. The second duty is to decide on an equitable distribution of the benefits. The third duty, which is the subject of this note, is to effect an appropriate mode of payment of the benefit. ${ }^{25}$ Unlike the first duty imposed on the board under section 37C, which is vague and provides no clear guidelines to the board, the duty to effect an appropriate mode of payment is unambiguous. It provides the board with clear and relevant factors to consider when deciding whether to deprive a guardian of the right to administer the benefits on behalf of a minor child. Additionally, it provides the board with options that constitute appropriate modes of payment, which include direct payment, payment into a member-nominated trust, and payment in instalments; payment into a beneficiary fund; and payment to a person recognised in law or appointed by a court as the person who is legally responsible for managing the affairs of a beneficiary or meeting his daily care needs. ${ }^{26}$

- Third, the determination in Kowa $v$ Corporate Selection Retirement Fund is particularly important because it acknowledged a practice prevalent in South Africa where grandparents raise their grandchildren without the formalities of legal guardianships. For example, there is a growing practice in South Africa where adult children who reside in cities or elsewhere entrust their

25 See, Mashego v SATU National Provident Fund [2007] 1 BPLR 229 (PFA) par 5.3. For a comprehensive discussion of these duties and the relevant determinations, see Marx and Hanekom (n 3) 208-214.

26 For further discussion about these alternatives payments, see Mafe $v$ Barloworld (SA) Retirement Fund Respondent par 34 and s 37C(2)(i)-(iii) as amended. 
children to the care of their parents without officially appointing them as legal guardians. ${ }^{27}$ The prevalence of HIVIAIDS has also exacerbated this practice, where grandparents become caregivers, and in all practical purposes guardians, in the sense that they live with the children, care for the children, and support and lead the children in their daily lives. This practice has also been confirmed by a study conducted by the University of Pretoria for the South African Department of Health. According to this study, one of the effects of the HIV and AIDS epidemic is the obligation of care that falls on grandparents, particularly grandmothers, which has increased the number of grandparents- and child-headed households. ${ }^{28}$ Therefore, the Adjudicator's ruling that the grandmother in Kowa $v$ Corporate Selection Retirement Fund was a guardian for purposes of section 37C, and therefore entitled to the common law right to administer the death benefit on behalf of the minor child, should be welcomed because it is consistent with the prevailing social and cultural practices in South Africa. ${ }^{29}$ Despite the above determinations, an open question remains in circumstances involving childheaded households, which is whether or not the Adjudicator would consider a child head of a household a guardian for the purposes of section $37 \mathrm{C}$ of the Act, and entitled to administer benefits on behalf of other minor beneficiaries.

- Fourth, the above determinations are important because in addition to their emphasis on the relevant factors previously announced in Ramanyelo $v$ Mine Workers Provident Fund, they also pronounce that the best interest of the child should be kept in mind in the analysis. In other words, the board

27 Debbie Budlender has noted that because of South Africa's history of migrant labour, and the lack of formal work opportunities in the rural areas, adults living in rural areas often move to urban centres in search of work, while their children remain in rural areas, to be cared for by grandparents or other family members. See, Children's Institute 2009 www.childrencount.ci.org.zal

28 See the Department of Health 2007 www.doh.gov.za/ and UP 2007 www.doh.gov.za/ ch 30 at 30-4 and 30-5.

29 See Ndlovu Grandparents' Experiences 64 discussing the fact that most learners in Kwazulu Natal are no longer in the care of their biological parents but are looked after by their grandparents. The author attributes this practice among other things to a general transference of responsibility common to the wider context of the extended family in African society. 
should do what is in the best interest of the child. This aspect of the ruling is important to the jurisprudence of the Adjudicator, who is obliged in terms of sections 7 and 39 of the Constitution ${ }^{30}$ to respect, protect, promote the spirit, import and fulfil the rights in the Bill of Rights. ${ }^{31}$ In this case, the Adjudicator's ruling respects, protects, promotes the values, spirit, and fulfils the rights of children contained in section 28 of the Constitution. This aspect of the ruling is also important because it contributes to the development of constitutional jurisprudence that reflects the Bill of Rights within the pension fund industry. This is a commendable practice because it ensures that the Constitution has an impact upon the pension fund industry as a whole, and pension members in particular. Put differently, it is good for South African democracy for pension members and/or beneficiaries to see the relevance of the Constitution to pension-related matters. ${ }^{32}$

- Fifth, the above determinations are important because of their emphasis on three considerations regarding modes of payment. The first is that direct payment whether to a minor or guardian is the default mode of payment; that the board should not ignore this in favour of other modes of payments provided for in section 37C. Put differently, when faced with a death-benefit distribution, the board should first consider direct payment of the benefit before other alternative modes of payment, and where there is a good reason both in law and fact not to effect a direct payment such other alternative modes of payments may be considered. The second is that the board must consult with the potential beneficiary before the board may pay a benefit into a trust or beneficiary fund. Recall that all of the complainants in the above determinations had complained that they had not been consulted by the board with regard to the decision to pay the benefits into a trust, and the Adjudicator set aside the board's decision in all the above

30 Constitution of the Republic of South Africa 1996. Hereafter the Constitution.

31 For some examples of determinations where the Adjudicator has discharged his responsibility under s 39 of the Constitution, see, Van der Merwe $v$ Southern Life Association [2000] 3 BPLR 321 (PFA) at 330; and Mtshixa v Mine Employee Pension Fund PFA/GA/4008/2005/MN unreported.

32 Other commentators have welcomed the Adjudicator's contribution to the development of constitutional jurisprudence in relation to the pension funds industry. See, Khumalo 2006 Pension World 7-9. 
determinations, from which it could be established that consultation is important and must be had in these matters. This aspect of consultation is also implied in the amended section 37C(2)(ii), which allows pension funds to pay death benefits to a trust nominated by the deceased member or a person recognised in law or appointed by a court as the person who is legally responsible for managing the affairs of a beneficiary or meeting his/her daily care needs. The third is that the cost implications of placing a benefit into a trust should also be considered. This is important because in the past boards have rarely felt obliged to consider the cost implication of paying a benefit into a trust or beneficiary fund. Despite previous rulings by the Adjudicator to consider the cost implications of placing benefits into a trust, $^{33}$ it is clear from Lebepe $v$ Premier Foods Provident Fund and Ramanyelo $v$ Mine Workers Provident Fund that the boards did not apply their minds to this consideration.

- Lastly, from a socio-political point of view the above determinations are important to address the perceived bias against African women by the pension industry. Previous legal authorities including Van Rij v Employees Liability Assurance Corporation, ${ }^{34}$ Woji v Santam Insurance, ${ }^{35}$ and South Insurance Association $v$ Bailey, ${ }^{36}$ on the question of the circumstances under which a guardian can be deprived of the right to administer benefits on behalf of his minor child, reveal certain elements of bias against African women who were entitled to lump sum benefits of one kind or another. It is apparent from these authorities that the courts' decisions to deprive the guardian of the right to administer the benefits was based on the rationale that since the African women involved were not formally educated and could not handle large sums of money, therefore they should not be entitled to receive lump sum benefits. Prior to the above determinations, the position in Van Rij v Employees Liability Assurance Corporation, Woji v Santam Insurance, and South Insurance Association $v$ Bailey provided a useful 
guidance in respect of the circumstances under which a guardian should be deprived of the right to administer benefits on behalf of his minor child. ${ }^{37}$ Therefore, the above determinations should be welcomed because they are likely to effectively eradicate this invidious practice from the pension fund industry.

\section{Criticism of the Adjudicator's failure to follow its own precedent}

The Adjudicator's holding in Moralo v Holcim South African Provident Fund and Mafe $v$ Barloworld (SA) Retirement Fund Respondent should be criticised for departing from the Adjudicator's established precedent. A tribunal such as the OPFA is required to have regard to its own precedent in adjudicating matters, and may depart from its own precedent provided it provides reasonable explanation for doing so. ${ }^{38}$ This doctrine (also known as the consistency doctrine) was clearly articulated by the United States Court of Appeals for the First Circuit in Davila-Bardales $v$ INS. ${ }^{39}$ In Davila-Bardales $v$ INS, the First Circuit overturned and remanded the decision of the Board of Immigration Appeals (BIA), a tribunal with functions and powers similar to those of the Adjudicator, when it disregarded its own precedent. The First Circuit noted that the law prohibits a tribunal from adopting significantly inconsistent policies and/or decisions that result in the creation of conflicting lines of precedent governing identical situations. It emphasised that the law demands certain orderliness. If a tribunal decides to depart significantly from its own precedent, it must confront the issue squarely and explain why the departure is reasonable. The First Circuit further noted that the prospects of a tribunal treating virtually identical legal issues differently in different cases without a semblance of a

37 Marx and Hanekom (n 3) 219.

38 See, eg, Hlathi v University of Fort Hare Retirement Fund PFA/EC/9015/2006 March 2009 where the Adjudicator explained why she reversed the decision and test adopted by a previous Adjudicator in Van der Merwe $v$ Central Retirement Annuity Fund [2005] 5 BPLR 463 (PFA) on how to determine factual dependants under s 37C. 
plausible explanation raises the kinds of concerns about arbitrary tribunal action that the consistency doctrine addresses. ${ }^{40}$

In Ramanyelo $v$ Mine Workers Provident Fund the Adjudicator established precedent when it ruled that "whether a guardian should be deprived the right to administer benefits on behalf of a minor child depends on the applications of the following relevant factors in making this decision: (1) the amount of the benefit; (2) the ability of the guardian to administer the moneys; (3) the qualification (or lack thereof) of the guardian to administer the moneys; (4) and the use of the benefit in such a manner that it can provide for the minor until he or she attains the age of majority. The Adjudicator in Lebepe $v$ Premier Foods Provident Fund affirmed the ruling in Ramanyelo $v$ Mine Workers Provident Fund, after concluding that the Provident Fund in that determination had not considered the relevant factors above. Furthermore, recall that in Kowa $v$ Corporate Selection Retirement Fund the Adjudicator reasoned and emphasised that in determining whether or not a guardian should administer benefits on behalf of his minor child, the board must consider the relevant factors announced in Ramanyelo $v$ Mine Workers Provident Fund and affirmed in Kowa $v$ Corporate Selection Retirement Fund. Similarly in Moralo $v$ Holcim South African Provident Fund and Mafe $v$ Barloworld (SA) Retirement Fund Respondent, the Adjudicator found that the boards had not considered the relevant factors in Ramanyelo $v$ Mine Workers Provident Fund and Kowa $v$ Corporate Selection Retirement Fund. However, the Adjudicator's order in Moralo $v$ Holcim South African Provident Fund was silent as to the minor children's share, which had also initially been paid into a trust.

Likewise, in Mafe $v$ Barloworld (SA) Retirement Fund Respondent, the Adjudicator ordered the retirement fund to re-exercise its discretion. These inconsistent outcomes by the Adjudicator on a similar set of facts should be criticised because they do not promote certainty in the pension fund industry. It is difficult for legal advisers to advise clients regarding the potential outcome of 
these matters. There was no explanation by the Adjudicator as to why given the similarity of the facts and legal issues in Lebepe $v$ Premier Foods Provident Fund and Moralo v Holcim South African Provident Fund, the outcomes were different.

Therefore, it is our contention that had the Adjudicator applied the precedent in Lebepe $v$ Premier Foods Provident Fund to the factual circumstances in Moralo v Holcim South African Provident Fund and Mafe v Barloworld (SA) Retirement Fund Respondent, it would have had to order the boards in these determinations to pay all of the benefits directly to the complainants. This remedy would have been in harmony with the consistency doctrine that prohibits the OPFA from adopting significantly inconsistent decisions that result in the creation of conflicting lines of precedent governing identical circumstances. Since the factual circumstances in Moralo $v$ Holcim South African Provident Fund and Mafe $v$ Barloworld (SA) Retirement Fund Respondent were identical to those in Lebepe $v$ Premier Foods Provident Fund, the Adjudicator should have granted similar remedies; and since the Adjudicator decided to depart significantly from its own precedent, it should have confronted the issue squarely and explained why the departure was reasonable as it has done in Hlathi $v$ University of Fort Hare Retirement Fund. ${ }^{41}$ In other words, the Adjudicator failed to explain why the remedy in Lebepe $v$ Premier Foods Provident Fund was not applied in Moralo $v$ Holcim South African Provident Fund and Mafe $v$ Barloworld (SA) Retirement Fund Respondent given the identical circumstances that gave rise to the complaint in these matters. Therefore, the Adjudicator erroneously failed to adhere to its own precedent when it granted inconsistent remedies in Moralo v Holcim South African Provident Fund, Mafe v Barloworld (SA) Retirement Fund Respondent and Lebepe $v$ Premier Foods Provident Fund.

Moreover, the circumstances and outcomes in Moralo v Holcim South African Provident Fund and Mafe $v$ Barloworld (SA) Retirement Fund Respondent created unacceptable circumstances whereby guardians were prevented from 
the adequate fulfilment of their responsibilities simply because the money they desperately need to enable them to fulfil their responsibility was sheltered in a trust. It is nearly impossible for a person in South Africa to raise two minor children on a monthly income of R200.00. Therefore, we submit that the Adjudicator should have issued similar orders, namely the payment of the entire benefit directly to the complainants involved, in Lebepe $v$ Premier Foods Provident Fund, Moralo $v$ Holcim South African Provident Fund and Mafe $v$ Barloworld (SA) Retirement Fund Respondent.

\section{$5 \quad$ Conclusion}

To conclude, the above determinations are extremely important given their interpretation of what constitutes an appropriate mode of payment and the circumstances under which a board may deprive a guardian of the right to administer benefits on behalf of minor beneficiaries. The above determinations should be welcomed because of their progressive interpretation of the Act and for setting an important precedent for pension fund practitioners and the boards. They also confirm that the Act is a remedial statute which should be liberally construed by the courts and tribunals to give effect to its purpose of enhancing social protection by granting rather than denying benefits to beneficiaries. Furthermore, the above determinations remain relevant to the recent amendment to the Act because the intention of the legislature seems to be that where a board is of the opinion that it would not be in the interest of a minor beneficiary that his benefit be paid to his parent or guardian (presumably because the parent or guardian is labouring under a legal disability such as prodigality, insolvency, mental disability or is incapable of managing his own affairs), the benefit may be paid to a registered beneficiary fund. ${ }^{42}$ This means that even with the recent amendments parents or guardians still face the challenge of being deprived of their right to administer benefits on behalf of minor beneficiaries, which is why the application of the criteria announced in the above determinations remains relevant. 
On a substantive and practical level, the above determinations demonstrate that when faced with a death benefit distribution, the board should first consider direct payment of the benefit before other alternative modes of payment, and where there is a good reason both in law and fact not to effect a direct payment such other alternative modes of payments may be considered. Regarding the effects of the above determinations on pension law, we submit that one of the key effects is that the invidious and biased practice of pension funds depriving most African women of the ability to administer death benefits on behalf of their minor children will probably be curbed. 


\section{Bibliography}

Khumalo 2006 Pension World

Khumalo S "Jurisprudential Role Played by the Pension Funds Adjudicator in SA Law" 2006 Pension World 7-9

Marx and Hanekom Manual

Marx G and Hanekom K The Manual on South African Retirement Funds and Other Employee Benefits (LexisNexis Durban 2007)

Mhango 2008 ILJ

Mhango M "The Duty to Investigate Factual Dependants: A Comment on

De Beerss v Hosaf Fibre Provident Fund" 2008 (29) Industrial Law Journal 2439-2446

Ndlovu Grandparents' Experiences

Ndlovu A Grandparent" Experiences of Inclusion at a School in Kwazulu Natal (MEd dissertation University of Johannesburg 2005)

\section{Register of legislation}

Children's Act 38 of 2005

Constitution of the Republic of South Africa 1996

Financial Services Laws General Amendment Act 22 of 2008

Pension Funds Act 24 of 1956

\section{Register of court cases}

Davila-Bardales v INS.27 F.3d 1 (1994)

Dhlamini v Smith and Another [2003] 7 BPLR 4894 (PFA)

Hlathi v University of Fort Hare Retirement Fund PFA/EC/9015/2006 March 2009

Kowa $v$ Corporate Selection Retirement Fund \& Another

PFA/GA/14151/2007/SM unreported

Lebepe v Premier Foods Provident Fund \& Others PFA/NP/5947/2005/RM Mafe $v$ Barloworld (SA) Retirement Fund Respondent PFA/FS/13033/07/CN Malatjie v Idwala Provident Fund [2005] 1 BPLR 45 (PFA) 
Mashego v SATU National Provident Fund \& Another [2007] 1 BPLR 229 (PFA) Moralo v Holcim South African Provident Fund PFA/GA/5400/2005/ZC Mtshixa v Mine Employee Pension Fund PFA/GA/4008/2005/MN unreported Ramanyelo v Mine Workers Provident Fund [2005] 1 BPLR 67 (PFA) Robinson v Boerhringer-Ingelheim Pension Scheme and Another [2003] 10 BPLR 5234 (PFA)

South Insurance Association Ltd v Bailey NO 198410 SA 98 (A)

Van der Merwe and Others $v$ Southern Life Association Ltd and Another [2000] 3 BPLR 321 (PFA)

Van Rij NO v Employees Liability Assurance Corporation Ltd 19644 SA 737

Woji v Santam Insurance Co Ltd 19811 SA 1020 (A)

\section{Register of internet resources}

Children's Institute 2009 www.childrencount.ci.org.za/

Children's Institute 2009 Children living in urban/rural areas

www.childrencount.ci.org.za/content.asp?TopLinkID=9\&PageID=27 [date of use 1 October 2008]

Department of Health 2007 www.doh.gov.za/

Department of Health 2007 Training Manual - Operational plan for Comprehensive HIV and AIDS Care, Management and Treatment for South Africa www.doh.gov.za/docs/misc/hiv/index.html [date of use 11 June 2009]

Swanepoel 2009 www.sanlam.co.za/

Swanepoel A "Monthly Report on Legal Developments in the Employee Benefits Industry" 2009 (34) Sanlam Trustee Review 1-4 www.sanlam.co.za/wps/wcm/connect/sanlam investments en/Sanlamlnve stments/Our+Businesses/Sanlam+Structured+Solutions+(SSS)/Industry+N ews/Trustee+Review/ [date of use 11 June 2009]

UP 2007 www.doh.gov.za/

University of Pretoria for the Department of National Health 2007 The 
impact of HIV on families, vulnerable groups and youth www.doh.gov.zal docs/misc/hiv/manual/impact families.pdf [date of use 11 June 2009]

\section{List of abbreviations}

BIA Board of Immigration Appeals

ch chapter(s)

CSRF Corporate Selection Retirement Fund

OPFA Office of the Pension Funds Adjudicator

par paragraph(s)

s $\quad$ section(s) 